\title{
Atherosclerotic disease regression with statins: studies using vascular markers
}

\author{
Diederick E. Grobbee*, Michiel L. Bots \\ Julius Center for Health Sciences and Primary Care, University Medical Center Utrecht, HP D01.335, P.O. Box 85500, Utrecht 3508 GA, The Netherlands
}

Received 9 October 2002; received in revised form 23 January 2004; accepted 23 January 2004

\begin{abstract}
Vascular imaging techniques enable identification of atherosclerosis in the subclinical phase and allow assessment of interventions to modify disease progression. Angiography has limited utility for tracking the progression of atherosclerosis because of its invasive nature, limited sensitivity for detecting early lesions and relatively low interscan reproducibility. Intravascular ultrasound (IVUS) and electron beam computed tomography (EBCT) are more senstive and reproducible; however, available data on their ability for tracking disease progression are few. Measurement of carotid intima media thickness (CIMT) by B-mode ultrasound is a well-validated procedure for this application. In comparison with angiography, CIMT demonstrates greater sensitivity for detecting early atherosclerosis and lipid-rich plaques that are vulnerable to rupture. Continued validation and development of imaging techniques, such as magnetic resonance imaging (MRI), will facilitate the assessment of atherosclerosis progression in intervention studies.

Stains are effective low-density lipoprotein cholesterol (LDL-C) lowering agents, and imaging studies have demonstrated their ability to slow progression and promote regression of atherosclerosis. The benefits of therapy on atherosclerosis regression appear to extend to soft atherosclerotic plaques that are still developing and treatment effects are independent of baseline LDL-C level. Hence, imaging studies support early intervention with statins in coronary heart disease patients, irrespective of lipid level.
\end{abstract}

(C) 2004 Elsevier Ireland Ltd. All rights reserved.

Keywords: Atherosclerosis progression; angiography; IVUS; EBCT; intima media thickness; statins

\section{Introduction}

Atherosclerosis is a progressive disease that starts early in life and is manifested clinically as coronary heart disease (CHD), cerebrovascular disorders or peripheral arterial disease. Various risk factors, such as raised low-density lipoprotein cholesterol (LDL-C) levels, smoking and hypertension, place stress on the arterial wall resulting in endothelial dysfunction and the onset of atherosclerosis $[1,2]$. The first stage in atherosclerotic lesion formation is a thickening of the intima that results from proliferation of smooth muscle cells. This thickening often begins early in life; approximately $17 \%$ of a western population have been shown to exhibit these early lesions by the age of 20 years [3]. Atherosclerosis progresses with the accumulation of lipids, carbohydrates, blood products, fibrous tissue and calcium deposits within the lesions, resulting in hard, calcified plaques $[2,4]$. The disease

\footnotetext{
* Corresponding author. Tel.: +31-30-2509358.

E-mail address: d.e.grobbee@jc.azu.nl (D.E. Grobbee).

URL: http://www.juliuscenter.nl.
}

may remain asymptomatic for many years as a result of remodelling of the arterial wall; initially the atherosclerotic lesion grows into the vessel wall, maintaining the diameter of the vessel lumen and thereby having little effect on blood flow [5]. However, further lesion progression may result in plaques protruding into the lumen of the artery, narrowing the vessel and ultimately leading to occlusion [2]. Vessel stenoses may be manifest clinically as stable conditions such as angina pectoris, although some patients may still remain asymptomatic for many years.

Acute manifestations of atherosclerosis such as unstable angina, acute myocardial infarction (MI), stroke or sudden cardiac death result from thrombosis following rupture of unstable plaques. Plaque stability is determined by the composition of the lesion-fibrous, calcified plaques are relatively stable, while soft plaques with a large lipid core, reduced numbers of smooth muscle cells and a thin fibrous cap are more vulnerable to rupture [6]. An acute coronary event resulting from thrombosis following plaque rupture is often the first clinical sign of disease; indeed, up to $62 \%$ of adult sudden deaths in Europe are attributed to atherosclerosis 
$[7,8]$. Hence, early assessment of the disease in the subclinical phase is important to identify patients at risk, who may benefit from risk factor intervention to slow progression of atherosclerosis and prevent the onset of symptoms.

Epidemiological studies have established elevated LDL-C levels as a major risk factor for the development of CHD $[9,10]$ and LDL-C lowering has been identified as the primary goal of therapy for disease prevention $[11,12]$. Statins (hydroxy-methylglutaryl coenzyme A reductase inhibitors) are recommended as first-line therapy for the treatment of dyslipidemia because of their effective LDL-C lowering and good tolerability $[11,12]$. Landmark clinical trials have demonstrated that statins reduce the risk of major coronary events by $20-40 \%$ [13-18], and statins have been shown to slow progression of atherosclerosis [19-21].

This paper examines the evidence from imaging studies for the efficacy of statins in slowing atherosclerosis progression and promoting regression of disease. The advantages and disadvantages of various imaging techniques will be compared in terms of their utility for tracking disease progression in intervention studies.

\section{Vascular markers of atherosclerotic burden}

The availability of several imaging techniques for use as surrogate markers of atherosclerotic burden has enabled the effects of statins to be examined at the vascular level. These imaging modalities, which include angiography, B-mode ultrasonography, intravascular ultrasonography (IVUS), magnetic resonance imaging (MRI) and electron beam computed tomography (EBCT), differ in terms of method of assessment, sensitivity and ease of use; these differences influence the applicability of the techniques to the assessment of atherosclerotic burden in clinical trial populations.

Quantitative coronary angiography (QCA) is an invasive technique that can be used to assess diffuse atherosclerotic changes on a per-patient basis by calculating a mean vessel diameter from serial measurements made along a coronary artery or segment. The modified Gensini score, an assessment of the degree of angiographically determined stenosis in various coronary segments, may be used to quantify the extent and severity of coronary atherosclerosis [22]. Alternatively, focal disease can be determined by measuring minimum lumen diameter (MLD), also known as minimum obstructive diameter (MOD), at the site of an atherosclerotic lesion. Variations over time can be visually evaluated from angiograms by an expert panel and the overall degree of change categorized as the global change score. A patient may be assessed as having progression or regression of atherosclerosis based upon measurement of change in percentage diameter, stenosis of existing plaques and on the appearance of new lesions. QCA findings predict future cardiovascular events $[23,24]$ and QCA-determined coronary atherosclerosis is related to atherosclerotic abnormalities elsewhere in the arterial system $[25,26]$. However, QCA is an invasive procedure, which also involves exposure to $\mathrm{X}$ ray radiation and is associated with certain morbidity and mortality risks that limit its use for studying progression of atherosclerosis in asymptomatic subjects. Moreover, QCA assessment of atherosclerotic plaques is based on measurement of luminal stenosis, and, as such, it has limited sensitivity for detecting early atherosclerotic lesions that do not protrude into the lumen.

Alternative techniques that directly image the morphology of the arterial wall, such as ultrasonography, may provide greater sensitivity in assessing progression of atherosclerotic disease. B-mode (two-dimensional) ultrasonography is a non-invasive ultrasound technique that has been used frequently for tracking the progression of atherosclerosis. Most of the evidence on atherosclerosis, its determinants and sequelae obtained by B-mode ultrasound has been acquired by evaluating the carotid arteries. The boundaries between the arterial lumen and intima, and between the media and adventitia of an image of the carotid artery, can be accurately and precisely identified using this technique $[27,28]$, enabling measurement of mean and maximum carotid intima media thickness (CIMT). The validity of CIMT as a marker of atherosclerotic burden has been demonstrated in numerous population- and hospital-based studies that have revealed a graded relationship between CHD risk factors and CIMT. In some studies, CIMT was related to absolute risk of cardiovascular disease as estimated by available risk functions [2931]. Also, an increased CIMT has been associated with the presence of atherosclerosis in the abdominal aorta [32], in the arteries of the lower extremities [33-35] and with coronary calcium assessed by EBCT [36-38]. Studies of the relationship between CIMT and coronary atherosclerosis, as assessed by QCA, generally show modest positive associations [25,29,39-47]. Risk of CHD and stroke has been shown to rise with increasing CIMT in some [48-54], but not all studies [55]. A CIMT progression rate of $\geq 0.03 \mathrm{~mm} /$ year in subjects with previous CHD may be considered clinically relevant because it has been associated with a doubling in the incidence of coronary events [50].

In addition to assessing CIMT as a continuous variable, B-mode ultrasonography provides information on the presence of atherosclerotic plaques based either on arbitrarily chosen cut-off points of CIMT, typically $>1.0-1.2 \mathrm{~mm}$ [56-58] or by an increase in CIMT of more than $50 \%$ compared with the adjacent CIMT. The plaque score, which is computed by summing the maximum thickness of all the CIMT complexes in the carotid artery [57] or as a sum of all plaques in all segments of the carotid artery, has been shown to relate to the QCA-determined Gensini score, and may be a more sensitive measure of the extent and severity of atherosclerosis than summation of CIMT [26]. However, few data are available on the use of plaque score as a marker of atherosclerosis progression.

IVUS is an invasive ultrasound procedure for imaging the arterial wall that enables tomographic assessment of 
plaque size and composition. The external elastic membrane, located at the border between the media and adventitia, can be visualized using IVUS. Atherosclerotic burden is often assessed by measurement of the plaque index, which is the percentage of the external elastic membrane area occupied by atheroma (plaque area/external elastic membrane area $\times 100$ ) [59]. Clinically, IVUS is used as an adjunct to angiography to improve diagnosis and aid intervention [59]; for example, unstable plaques that are not readily identified by angiography may be more easily detected by IVUS as areas of low echogenicity [60]. In patients with suspected coronary disease with no angiographically documented atherosclerosis, IVUS frequently detects occult disease [61-63], indicating the low sensitivity of QCA for assessment of early atherosclerosis. However, IVUS is an invasive procedure, and, given the availability of non-invasive ultrasound techniques, this may limit its use in intervention studies.

EBCT, a technique that detects coronary artery calcification $[64,65]$, is a non-invasive method with potential for tracking progression in calcification of atherosclerotic plaques. As atherosclerosis develops, calcium is deposited within lesions in a process that resembles bone formation $[65,66]$. The traditional measure of coronary calcium derived from the EBCT scan is the Agatston calcium score, which is based on the area of calcium deposits and the maximum density within the lesion [67]. Evidence is accumulating for a relationship between the presence of coronary calcium and cardiovascular risk factors [68-70]. Also, coronary calcium correlates with atherosclerosis in the carotid arteries, the abdominal aorta and the arteries of the lower extremities [38]. Moreover, coronary calcium has been shown to predict cardiovascular events in patients and asymptomatic subjects [71,72]. However, the calcium score measurement is reported to have low interscan reproducibility, making it unsuitable for assessing changes in plaque size in serial recordings [71]. The calcium volume score (CVS), which is dependent upon plaque volume rather than density $[73,74]$, demonstrates better interscan reproducibility. It is therefore likely to be a more appropriate marker for assessing changes in the rate of coronary atherosclerosis progression within a relatively short period [64]. However, few intervention studies using EBCT have been performed to date and investigators are cautioned that small changes in the volume of a calcified plaque observed over time $(\leq 15 \%$ after 1 year of follow-up) might not always be indicative of disease progression [74].

\section{Statin therapy and vascular markers of atheroscle- rotic progression}

The effects of statin therapy on the progression of atherosclerosis have been examined in several clinical trials using vascular imaging techniques (Table 1). The results of these trials to quantify the effects of treatment on progression, stabilization or regression of atherosclerosis are significantly influenced by the assessment technique employed.

\subsection{The angiographic trials}

Several trials to date have used QCA to investigate the effects of statin monotherapy upon atherosclerotic progression (Tables 1 and 2). Due to the invasive nature of QCA, statin trials using this imaging modality are confined to the assessment of atherosclerosis progression in patients with established CHD. Quantitative comparisons between studies are limited as a result of a lack of uniformity in study design and angiographic methods used. However, these QCA trials have consistently demonstrated significantly smaller changes in MLD in the treatment group compared with placebo (Table 2), indicating that statin therapy slows progression of atherosclerosis. In the Monitored Atherosclerosis Regression Study (MARS), the effect of treatment on the primary end point, change in mean percent stenosis ( $1.6 \%$ vs. $2.2 \%$ for placebo), and on change in MLD (Table 2) were not statistically significant; however, patients receiving lovastatin exhibited significantly less disease progression as indicated by the mean global change score $(0.41$ vs. 0.88 for placebo; $P=0.002)$ [75].

The effects of statin therapy have been analyzed according to baseline severity of disease in a number of QCA trials. In MARS and the Multicentre Anti-atheroma Study (MAAS), statin therapy slowed progression to a greater extent in large plaques that narrowed the lumen to $<50 \%$ compared with smaller lesions $[19,75]$. In contrast, the effects of therapy were more pronounced on lesions causing $<50 \%$ stenosis than larger plaques in the Canadian Coronary Atherosclerosis Intervention Trial (CCAIT) [76] and the Pravastatin Limitation of Atherosclerosis in the Coronary Arteries Study (PLAC I) [21]. Together, these studies indicate that the benefits of statin therapy extend to smaller lesions. Moreover, statin therapy has been shown to approximately halve the appearance of new QCA-defined coronary lesions in CCAIT [76], PLAC I [21], the Lipoprotein and Coronary Atherosclerosis Study (LCAS) [77] and MAAS [19], and it has been suggested that this may be more important than the effect of statins on established plaques [76].

The benefits of statin therapy were shown to be independent of baseline LDL-C level in the REgression GRowth Evaluation Statin Study (REGRESS) [20] and LCAS [77]. Indeed, in LCAS, fluvastatin treatment was associated with significant benefits even in normocholesterolemic patients (LDL-C $<3.4 \mathrm{mmol} / 1[130 \mathrm{mg} / \mathrm{dl}]$ ) [77]. Similar results were found in the Simvastatin/Enalapril Coronary Atherosclerosis Trial (SCAT), which examined the effect of LDL-C lowering with simvastatin in normocholesterolemic subjects; simvastatin significantly reduced 
Table 1

Summary of statin trials measuring atherosclerotic progression

\begin{tabular}{|c|c|c|c|c|c|c|c|}
\hline Trial & Patient details & Baseline cholesterol level & $N$ & $\begin{array}{l}\text { Statin treatment } \\
\text { regimen }(\mathrm{mg} / \text { day })\end{array}$ & $\begin{array}{l}\text { Length } \\
\text { of study } \\
\text { (years) }\end{array}$ & $\begin{array}{l}\text { Measurement } \\
\text { of lipid levels }\end{array}$ & $\begin{array}{l}\text { Measurement } \\
\text { of CHD events/ } \\
\text { mortality }\end{array}$ \\
\hline \multicolumn{8}{|l|}{ Angiographic trials } \\
\hline MARS [75] & CHD patients ( $91 \%$ male) & $\begin{array}{l}\text { TC: } 4.9-7.6 \mathrm{mmol} / 1 \\
(190-295 \mathrm{mg} / \mathrm{dl})\end{array}$ & 270 & Lovastatin 80 & 2.2 & $\mathrm{Y}$ & $\mathrm{Y}$ \\
\hline CCAIT [76] & CHD patients ( $81 \%$ male $)$ & $\begin{array}{l}\text { TC: } 5.7-7.8 \mathrm{mmol} / 1 \\
(220-300 \mathrm{mg} / \mathrm{dl})\end{array}$ & 331 & Lovastatin $20-80$ & 2 & $\mathrm{Y}$ & $\mathrm{Y}$ \\
\hline PLAC I [21] & CHD patients ( $38 \%$ male) & $\begin{array}{l}\text { LDL-C: } 3.4-<4.9 \mathrm{mmol} / 1 \\
(130-<190 \mathrm{mg} / \mathrm{dl})\end{array}$ & 408 & Pravastatin 40 & 3 & $\mathrm{Y}$ & $\mathrm{Y}$ \\
\hline REGRESS [20] & Male CHD patients & $\begin{array}{l}\mathrm{TC}: 4.0-<8.0 \mathrm{mmol} / 1 \\
(155-<310 \mathrm{mg} / \mathrm{dl})\end{array}$ & 885 & Pravastatin $40^{\mathrm{a}}$ & 2 & $\mathrm{Y}$ & $\mathrm{Y}$ \\
\hline LCAS [77] & CHD patients ( $81 \%$ male $)$ & $\begin{array}{l}\text { LDL-C: } 3.0-4.9 \mathrm{mmol} / 1 \\
(115-190 \mathrm{mg} / \mathrm{dl})\end{array}$ & 429 & Fluvastatin $40^{\mathrm{b}}$ & 2.5 & $\mathrm{Y}$ & $\mathrm{Y}$ \\
\hline $\begin{array}{l}\text { CIS (Coronary } \\
\text { Intervention } \\
\text { Study) }[78]\end{array}$ & Male CHD patients & $\begin{array}{l}\text { TC: } 5.3-9.0 \mathrm{mmol} / 1 \\
(207-350 \mathrm{mg} / \mathrm{dl})\end{array}$ & 254 & $\begin{array}{l}\text { Simvastatin } \\
20-40^{c}\end{array}$ & 2.3 & $\mathrm{Y}$ & $\mathrm{Y}$ \\
\hline MAAS [19] & CHD patients ( $88 \%$ male $)$ & $\begin{array}{l}\text { TC: } 5.5-8.0 \mathrm{mmol} / 1 \\
(213-310 \mathrm{mg} / \mathrm{dl})\end{array}$ & 381 & Simvastatin 20 & 4 & $\mathrm{Y}$ & $\mathrm{Y}$ \\
\hline SCAT [79] & $\begin{array}{l}\text { Patients }(89 \% \text { male }) \\
\text { with angiographic } \\
\text { documented } \\
\text { coronary atherosclerosis }\end{array}$ & $\begin{array}{l}\mathrm{TC}: 4.1-6.2 \mathrm{mmol} / 1 \\
(159-240 \mathrm{mg} / \mathrm{dl})\end{array}$ & 460 & Simvastatin 40 & 4 & $\mathrm{Y}$ & $\mathrm{Y}$ \\
\hline \multicolumn{8}{|c|}{ B-mode ultrasound trials } \\
\hline $\begin{array}{l}\text { REGRESS } \\
\text { subgroup [80] }\end{array}$ & Male CHD patients & $\begin{array}{l}\mathrm{TC}: 4.0-<8.0 \mathrm{mmol} / 1 \\
(155-<310 \mathrm{mg} / \mathrm{dl})\end{array}$ & 255 & Pravastatin 40 & 2 & $\mathrm{Y}$ & $\mathrm{Y}$ \\
\hline PLAC II [81] & $\begin{array}{l}\text { CHD patients } \\
(85 \% \text { men })[82]\end{array}$ & $\begin{array}{l}\text { LDL-C: } 60-90 \text { th } \\
\text { percentile for } \\
\text { age and sex }\end{array}$ & 151 & Pravastatin $10-40$ & 3 & $\mathrm{Y}$ & $\mathrm{Y}$ \\
\hline LIPID [83] & CHD patients ( $88 \%$ male $)$ & $\begin{array}{l}\text { TC: } 4.0-7.0 \mathrm{mmol} / 1 \\
(155-271 \mathrm{mg} / \mathrm{dl})\end{array}$ & 522 & Pravastatin 40 & 4 & $\mathrm{Y}$ & $\mathrm{Y}$ \\
\hline $\begin{array}{l}\text { MARS subgroup } \\
\text { [84] }\end{array}$ & CHD patients ( $92 \%$ male) & $\begin{array}{l}\text { TC: } 4.9-7.6 \mathrm{mmol} / 1 \\
(190-295 \mathrm{mg} / \mathrm{dl})\end{array}$ & 188 & Lovastatin 80 & $2-4$ & $\mathrm{Y}$ & $\mathrm{Y}$ \\
\hline ASAP [85] & $\begin{array}{l}\text { Patients ( } 39 \% \text { male) with } \\
\text { familial hypercholesterolemia. } \\
31 \% \text { with a history of CHD }\end{array}$ & $\begin{array}{l}\text { LDL-C: }>4.5 \mathrm{mmol} / \mathrm{l} \\
(174 \mathrm{mg} / \mathrm{dl})\end{array}$ & 325 & $\begin{array}{l}\text { Atorvastatin } 80 \\
\text { vs. simvastatin } 40\end{array}$ & 2 & $\mathrm{Y}$ & $\mathrm{N}$ \\
\hline $\begin{array}{c}\text { ARBITER } \\
{[86,87]}\end{array}$ & $\begin{array}{l}\text { Male and female } \\
\text { asymptomatic and } \\
\text { CHD patients }\end{array}$ & $\begin{array}{l}\mathrm{TC}: \geq 4.1 \mathrm{mmol} / 1 \\
(160 \mathrm{mg} / \mathrm{dl})\end{array}$ & 161 & $\begin{array}{l}\text { Atorvastatin } 80 \\
\text { vs. pravastatin } 40\end{array}$ & 1 & $\mathrm{Y}$ & $\mathrm{N}$ \\
\hline ACAPS [88] & $\begin{array}{l}\text { Patients }(52 \% \text { male }) \text { with } \\
\text { asymptomatic atherosclerosis }\end{array}$ & $\begin{array}{l}\text { LDL-C: } 3.4-4.9 \mathrm{mmol} / 1 \\
(130-189 \mathrm{mg} / \mathrm{dl})\end{array}$ & 919 & Lovastatin $20-40$ & 3 & $\mathrm{Y}$ & $\mathrm{Y}$ \\
\hline CAIUS [27] & $\begin{array}{l}\text { Patients }(53 \% \text { male) with } \\
\text { asymptomatic atherosclerosis }\end{array}$ & $\begin{array}{l}\text { LDL-C: } 3.9-6.5 \mathrm{mmol} / 1 \\
(150-250 \mathrm{mg} / \mathrm{dl})\end{array}$ & 305 & Pravastatin 40 & 3 & $\mathrm{Y}$ & $\mathrm{Y}$ \\
\hline KAPS [89] & $\begin{array}{l}\text { Male patients with } \\
\text { asymptomatic atherosclerosis }\end{array}$ & $\begin{array}{l}\text { LDL-C: }>4.0 \mathrm{mmol} / 1 \\
(155 \mathrm{mg} / \mathrm{dl})\end{array}$ & 424 & Pravastatin 40 & 3 & $\mathrm{Y}$ & $\mathrm{Y}$ \\
\hline BCAPS [58] & $\begin{array}{l}\text { Subjects ( } 46 \% \text { male) with } \\
\text { asymptomatic atherosclerosis }\end{array}$ & $\begin{array}{l}\mathrm{TC}: \leq 8.0 \mathrm{mmol} / 1 \\
(310 \mathrm{mg} / \mathrm{dl})\end{array}$ & 793 & Fluvastatin 40 & 3 & $\mathrm{Y}$ & $\mathrm{Y}$ \\
\hline METEOR [90] & $\begin{array}{l}\text { Male and female subjects } \\
\text { at low risk of } \mathrm{CHD}\end{array}$ & $\begin{array}{l}\text { LDL-C: } 3.1-<4.1 \mathrm{mmol} / 1 \\
(120-<160 \mathrm{mg} / \mathrm{dl}) \text { for } \\
\text { patients with a } 10 \text {-year CHD } \\
\text { risk of }<10 \% ; 3.1-<4.9 \\
\text { mmol/1 }(120-<190 \mathrm{mg} / \mathrm{dl}) \text { for } \\
\text { patients with no additional } \\
\text { CHD risk factor other than age }\end{array}$ & 840 & Rosuvastatin 40 & 2 & $\mathrm{Y}$ & $\mathrm{N}$ \\
\hline \multicolumn{8}{|l|}{ IVUS trials } \\
\hline Takagi et al. [91] & $\begin{array}{l}\text { Male patients with CHD who } \\
\text { had undergone PTCA }\end{array}$ & $\begin{array}{l}\text { TC: } 5.2-6.8 \mathrm{mmol} / 1 \\
(200-260 \mathrm{mg} / \mathrm{dl})\end{array}$ & 36 & Pravastatin 10 & 3 & $\mathrm{Y}$ & $\mathrm{Y}$ \\
\hline $\begin{array}{l}\text { Hagenaars } \\
\text { et al. [92] }\end{array}$ & $\begin{array}{l}\text { Patients ( } 90 \% \text { male) with } \\
\text { CHD undergoing PTCA }\end{array}$ & NS & 10 & Statin monotherapy & 1 & $\mathrm{~N}$ & $\mathrm{~N}$ \\
\hline REVERSAL [59] & $\begin{array}{l}\text { Male and female CHD } \\
\text { patients }\end{array}$ & $\begin{array}{l}\text { LDL-C: } 3.2-5.4 \mathrm{mmol} / 1 \\
(125-210 \mathrm{mg} / \mathrm{dl})^{\mathrm{e}}\end{array}$ & $502^{\mathrm{e}}$ & $\begin{array}{l}\text { Atorvastatin } 80 \\
\text { vs. pravastatin } 40\end{array}$ & 1.5 & $\mathrm{Y}$ & $\mathrm{N}$ \\
\hline
\end{tabular}


Table 1 (continued)

\begin{tabular}{|c|c|c|c|c|c|c|c|}
\hline Trial & Patient details & Baseline cholesterol level & $N$ & $\begin{array}{l}\text { Statin treatment } \\
\text { regimen (mg/day) }\end{array}$ & $\begin{array}{l}\text { Length } \\
\text { of study } \\
\text { (years) }\end{array}$ & $\begin{array}{l}\text { Measurement } \\
\text { of lipid levels }\end{array}$ & $\begin{array}{l}\text { Measurement } \\
\text { of CHD events/ } \\
\text { mortality }\end{array}$ \\
\hline \multicolumn{8}{|l|}{ IVUS trials } \\
\hline SARIS [93] & $\begin{array}{l}\text { Male and female patients } \\
\text { with CHD eligible for } \\
\text { balloon angioplasty } \\
\text { and/or stent placement }\end{array}$ & $\begin{array}{l}\text { LDL-C: } \leq 3.0 \mathrm{mmol} / 1 \\
(116 \mathrm{mg} / \mathrm{dl})\end{array}$ & 50 & $\begin{array}{l}\text { Atorvastatin } 10 \\
\text { vs. } 80\end{array}$ & 1 & NA & NA \\
\hline ASTEROID [94] & $\begin{array}{l}\text { Male and female CHD } \\
\text { patients }\end{array}$ & NS & 450 & Rosuvastatin 40 & 2 & Y & $\mathrm{N}$ \\
\hline \multicolumn{8}{|l|}{ EBCT trials } \\
\hline Callister et al. [73] & $\begin{array}{l}\text { Asymptomatic patients } \\
(61 \% \text { male })\end{array}$ & $\begin{array}{l}\text { Mean LDL-C } \mathrm{C}^{\mathrm{f}}: 3.8 \mathrm{mmol} / \mathrm{l} \\
(147 \mathrm{mg} / \mathrm{dl}) \text { for untreated } \\
\text { patients; } 3.6 \mathrm{mmol} / 1 \\
(139 \mathrm{mg} / \mathrm{dl}) \text { for patients } \\
\text { treated to } \geq 3.1 \mathrm{mmol} \\
(120 \mathrm{mg} / \mathrm{dl}) ; 2.6 \mathrm{mmol} / 1 \\
(100 \mathrm{mg} / \mathrm{dl}) \text { for patients } \\
\text { treated to below } 3.1 \mathrm{mmol} \\
(120 \mathrm{mg} / \mathrm{dl})\end{array}$ & 149 & Statin monotherapy & $1-1.25$ & Y & $\mathrm{N}$ \\
\hline $\begin{array}{l}\text { Achenbach } \\
\text { et al. [95] }\end{array}$ & $\begin{array}{l}\text { Asymptomatic patients } \\
(89 \% \text { male })\end{array}$ & $\begin{array}{l}\text { LDL-C: } \geq 3.4 \mathrm{mmol} / 1 \\
(130 \mathrm{mg} / \mathrm{dl})\end{array}$ & 66 & Cerivastatin 0.3 & $1^{\mathrm{g}}$ & Y & $\mathrm{Y}$ \\
\hline BELLES [96] & Postmenopausal women & $\begin{array}{l}\text { LDL-C: above NCEP } \\
\text { ATP II target [97] }\end{array}$ & 600 & $\begin{array}{l}\text { Atorvastatin } 80 \\
\text { vs. pravastatin } 40\end{array}$ & 1 & Y & $\mathrm{N}$ \\
\hline
\end{tabular}

$\mathrm{CHD}=$ coronary heart disease, $\mathrm{TC}=$ total cholesterol, LDL-C $=$ low-density lipoprotein cholesterol, $\mathrm{PTCA}=$ percutaneous transluminal coronary angioplasty, $\mathrm{NS}=$ not stated, $\mathrm{NA}=$ not available.

${ }^{\text {a }}$ Patients whose TC level rose above $8.0 \mathrm{mmol} / 1(310 \mathrm{mg} / \mathrm{dl})$ on repeated assessments and who did not respond to enhanced dietary therapy had open-label cholestyramine added to their treatment.

${ }^{\mathrm{b}}$ A subgroup of patients received cholestyramine in addition to fluvastatin.

${ }^{\mathrm{c}}$ A resin was added at 12 weeks of treatment if LDL-C was $>3.1 \mathrm{mmol} / \mathrm{l}(120 \mathrm{mg} / \mathrm{dl})$ in the simvastatin group or $>6.5 \mathrm{mmol} / 1$ ( $\left.250 \mathrm{mg} / \mathrm{dl}\right)$ in the placebo group.

${ }^{\mathrm{d}}$ A history of MI was reported in $<10 \%$ of subjects.

${ }^{\mathrm{e}}$ Data presented at the American Heart Association Meeting 2003.

${ }^{\mathrm{f}}$ Average LDL-C throughout the study.

${ }^{g}$ Length of treatment period.

the mean change in MLD (Table 2) and the percent change in maximum stenosis compared with placebo $(1.67 \%$ vs. $3.83 \%$, respectively; $P=0.0003)$ [79]. The findings of these QCA trials are consistent with those of the recent Heart Protection Study (HPS), which demonstrated that simvastatin reduced the risk of CHD mortality and morbidity among patients with baseline LDL-C below recommended target levels [18].

Table 2

Placebo-controlled angiography trials measuring mean change in MLD

\begin{tabular}{|c|c|c|c|c|c|c|c|}
\hline \multirow[t]{2}{*}{ Trial } & \multirow[t]{2}{*}{ Statin (mg/day) } & \multicolumn{3}{|c|}{$\%$ LDL-C lowering } & \multicolumn{3}{|c|}{ Mean change in MLD (mm) } \\
\hline & & Treatment & Placebo & $P$ & Treatment & Placebo & $P$ \\
\hline MARS [75] & Lovastatin 80 & -38.0 & -0.9 & $<0.001$ & -0.03 & -0.06 & 0.20 \\
\hline CCAIT [76] & Lovastatin $20-80$ & -29.0 & -1.6 & $<0.001$ & -0.05 & -0.09 & 0.01 \\
\hline PLAC I [21] & Pravastatin 40 & -28 & +1 & $<0.001$ & $-0.03^{\mathrm{a}}$ & $-0.05^{\mathrm{a}}$ & 0.04 \\
\hline REGRESS $^{\mathrm{b}}[20]$ & Pravastatin 40 & -24.7 & +2.1 & $<0.001$ & $-0.03^{\mathrm{c}}$ & $-0.09^{\mathrm{c}}$ & 0.001 \\
\hline $\operatorname{LCAS}^{\mathrm{d}}[77]$ & Fluvastatin 40 & -22.5 & -2.2 & $<0.0001$ & -0.024 & -0.094 & 0.0161 \\
\hline $\operatorname{CIS}^{\mathrm{e}}[78]$ & Simvastatin $20-40$ & $-35.0^{\mathrm{f}}$ & $\mathrm{NA}^{\mathrm{g}}$ & $<0.0001$ & -0.02 & -0.10 & 0.002 \\
\hline MAAS $^{\mathrm{b}}[19]$ & Simvastatin 20 & -31.1 & +0.7 & $<0.001$ & -0.04 & -0.13 & 0.007 \\
\hline SCAT [79] & Simvastatin 40 & -30.5 & +3.5 & $<0.001$ & -0.09 & -0.16 & 0.0001 \\
\hline
\end{tabular}

LDL-C = low-density lipoprotein cholesterol.

${ }^{\text {a }}$ Value shown for mean change in MLD per year.

${ }^{\mathrm{b}}$ Values for percentage change in LDL-C have been calculated from absolute values presented in source reference.

${ }^{\mathrm{c}}$ Median, defined as MOD.

${ }^{\mathrm{d}}$ A subgroup of patients received cholestyramine in addition to fluvastatin. Data presented are for fluvastatin monotherapy.

${ }^{\mathrm{e}}$ Lipid levels measured over 30 months, angiographic end points over a mean of 2.3 years.

$\mathrm{f}_{\%} \%$ difference vs. placebo.

${ }^{\mathrm{g}} \mathrm{NA}=$ not available. 
A number of QCA trials have examined the effect of statin therapy on the risk of coronary events, although these studies were not specifically designed to detect differences in the incidence of clinical end points between treatment groups. In REGRESS, $89 \%$ of pravastatin-treated patients remained free of clinical events compared with $81 \%$ in the placebo group $(P=0.002)$. Similarly, the incidence of MI (fatal and nonfatal) was significantly reduced in patients receiving pravastatin therapy in comparison with placebo (8 events vs. 17; risk reduction 53\%; $P \leq 0.05$ ) in PLAC I [21]. In agreement with these findings, the incidence of cardiac morbidity was lower in the fluvastatin treatment group compared with placebo (14.5\% vs. $19.1 \%)$ in LCAS, although this difference did not achieve statistical significance [77]. In these studies, the effects of therapy on clinical end points is consistent with the benefits of statin therapy on QCA measures, thereby demonstrating further the validity of QCA as a surrogate marker for assessing atherosclerosis progression.

\subsection{B-mode ultrasound trials}

Several studies have examined the effect of statin therapy on the rate of progression of CIMT measured by B-mode ultrasonography (Tables 1 and 3). The REGRESS subgroup [80], Pravastatin, Lipids and Atherosclerosis in the Carotids (PLAC II) [81], the Long-term Intervention with Pravastatin in Ischemic Disease Trial subgroup (LIPID) [83] and MARS subgroup [84] studies examined the effect of statin therapy, in comparison with placebo, on B-mode ultrasound in patients with CHD (Table 1). Statin therapy caused regression of CIMT compared with baseline in REGRESS, LIPID and MARS, while progression of CIMT or no change was observed in the placebo groups (Table 3). In the PLAC II
Study, progression of mean maximum CIMT was reduced by $12 \%$ with pravastatin therapy compared with placebo ( 0.0593 vs. $0.0675 \mathrm{~mm} /$ year); however, this treatment effect was not statistically significant and the effect of pravastatin on CIMT appeared to be limited to the common carotid artery ( $P=0.03$; Table 3$)$ [81].

The benefit of statin therapy on CIMT has been shown to be associated with improved clinical outcome. For example, in the REGRESS CIMT substudy, $90.1 \%$ of patients treated with pravastatin remained event free during the 2-year treatment period compared with $79.8 \%$ of placebo patients $(P=0.02)$ [80]. Similarly, in PLAC II a $60 \%$ reduction in the incidence of coronary events was observed in the pravastatintreated patients compared with those receiving placebo [81].

The Atorvastatin vs. Simvastatin on Atherosclerotic Progression (ASAP) Study [85] and the ARterial Biology for the Investigation of the Treatment Effects of Reducing Cholesterol (ARBITER) Trial [87] highlighted differences in the efficacy of statins in slowing or reversing atherosclerotic progression. In ASAP, atorvastatin reduced CIMT in patients with familial hypercholesterolemia by $0.031 \mathrm{~mm}$ over the 2year treatment period [85]. In contrast, CIMT increased by $0.036 \mathrm{~mm}$ with simvastatin therapy $(P=0.0001$ for the difference between treatments). Regression of CIMT was observed in $66 \%$ of patients in the atorvastatin group compared with $42 \%$ of patients treated with simvastatin. Patients with high baseline CIMT values responded better to treatment with atorvastatin than those with low baseline values. Both statins are effective LDL-C lowering agents, although atorvastatin demonstrated a significantly greater reduction in LDL-C level compared with simvastatin $(-50.5 \%$ vs. $-41.2 \% ; P=0.0001)$. ARBITER compared change in CIMT following 12 months of treatment with atorvastatin or pravastatin [87]. Consistent with the results of ASAP, a larger

Table 3

Placebo-controlled B-mode ultrasound statin trials measuring mean change from baseline in LDL-C level and CIMT

\begin{tabular}{|c|c|c|c|c|c|c|c|}
\hline \multirow[t]{2}{*}{ Trial } & \multirow[t]{2}{*}{ Statin (mg/day) } & \multicolumn{3}{|c|}{$\%$ LDL-C lowering } & \multicolumn{3}{|c|}{ Mean change in CIMT (mm/year) } \\
\hline & & Treatment & Placebo & $P$ & Treatment & Placebo & $P$ \\
\hline REGRESS $^{\mathrm{a}}[80]$ & Pravastatin 40 & -29 & -1 & $<0.001$ & $-0.05^{\mathrm{b}, \mathrm{c}}$ & $0^{\mathrm{b}, \mathrm{c}}$ & 0.0085 \\
\hline PLAC II $^{\mathrm{a}}[81]$ & Pravastatin $10-40$ & -28 & +1 & $<0.001$ & $+0.0295^{\mathrm{d}}$ & $+0.0456^{\mathrm{d}}$ & 0.03 \\
\hline $\operatorname{LIPID}^{\mathrm{a}}[83]$ & Pravastatin 40 & $-28^{\mathrm{e}}$ & $-5^{\mathrm{e}}$ & $<0.0001$ & $-0.014^{\mathrm{f}, \mathrm{g}}$ & $+0.048^{\mathrm{f}, \mathrm{g}}$ & $<0.0001$ \\
\hline MARS [84] & Lovastatin 80 & -45 & -2 & $<0.001$ & $-0.038^{\mathrm{c}, \mathrm{f}}$ & $+0.019^{\mathrm{c}, \mathrm{f}}$ & $<0.001$ \\
\hline ACAPS [88] & Lovastatin $20-40$ & -28 & 0 & $<0.0001$ & $-0.009^{\mathrm{h}}$ & $+0.006^{\mathrm{h}}$ & 0.001 \\
\hline CAIUS $^{\mathrm{a}}[27]$ & Pravastatin 40 & -22 & +2 & 0.0001 & $-0.0043^{\mathrm{h}}$ & $+0.0089^{\mathrm{h}}$ & 0.0007 \\
\hline KAPS [89] & Pravastatin 40 & -27 & +2 & $<0.001$ & $+0.017^{\mathrm{h}}$ & $+0.031^{\mathrm{h}}$ & 0.005 \\
\hline \multirow[t]{2}{*}{ BCAPS [58] } & Fluvastatin 40 & -23 & 0 & - & $+0.011^{\mathrm{e}, \mathrm{f}}$ & $+0.0036^{\mathrm{e}, \mathrm{f}}$ & 0.002 \\
\hline & & & & & $+0.170^{\mathrm{e}, \mathrm{i}}$ & $+0.211^{\mathrm{e}, \mathrm{i}}$ & $>0.05$ \\
\hline
\end{tabular}

LDL-C = low-density lipoprotein cholesterol.

${ }^{\text {a }}$ Values for percentage change in LDL-C have been calculated from absolute values presented in source reference.

${ }^{\mathrm{b}}$ Combined mean intima media thickness of femoral and carotid arteries.

${ }^{\mathrm{c}}$ Mean change from baseline after 2 years.

${ }^{\mathrm{d}}$ Mean maximal CIMT of the common carotid artery.

${ }^{\mathrm{e}}$ Change from baseline after 3 years.

${ }^{\mathrm{f}}$ Mean CIMT of the common carotid artery.

${ }^{\mathrm{g}}$ Mean change from baseline after 4 years.

${ }^{\mathrm{h}}$ Mean maximal CIMT.

${ }^{\mathrm{i}}$ Mean CIMT of the carotid bifurcation. 
reduction in LDL-C was associated with greater atherosclerosis regression; pravastatin reduced LDL-C by $27.2 \%$ and CIMT increased by $0.025 \mathrm{~mm}$ over the study period, while a LDL-C reduction of $48.5 \%$ with atorvastatin $(P<0.001$ vs. pravastatin) was associated with a reduction in CIMT of $0.034 \mathrm{~mm}$ ( $P=0.03$ vs. pravastatin). However, the observed differences between the statins in their effect on disease progression cannot be entirely accounted for by differences in their LDL-C lowering efficacy and may be influenced by their non-lipid or pleiotropic effects [98].

The non-invasive nature of B-mode ultrasound has facilitated its use in clinical trials examining the effects of statin therapy on atherosclerosis progression in asymptomatic subjects with early atherosclerotic disease (Table 1). Consistent with the results of B-mode ultrasound trials in CHD patients, these studies have demonstrated significant regression (Asymptomatic Carotid Artery Progression Study [ACAPS] [88] and Carotid Atherosclerosis Italian Ultrasound Study [CAIUS] [27]) or slowing of progression (Kuopio Atherosclerosis Prevention Study [KAPS] [89] and Beta-Blocker Cholesterol-Lowering Asymptomatic Plaque Study [BCAPS] [58]) of CIMT with statin therapy (Table 3), and benefits of therapy were evident after as little as 6-12 months $[27,88]$.

The Measuring Effects on intima media Thickness-an Evaluation Of Rosuvastatin (METEOR) Study, which will examine the effect of rosuvastatin therapy on atherosclerosis using B-mode ultrasound, is currently ongoing [90]. Rosuvastatin has demonstrated greater efficacy in reducing LDL-C levels compared with atorvastatin, pravastatin and simvastatin [99-103]. METEOR is a placebo-controlled study assessing the effect of rosuvastatin on progression and regression of CIMT in asymptomatic patients with low risk of CHD who have evidence of atherosclerotic disease [90].

\subsection{IVUS trials}

Few intervention studies performed to date have used IVUS to examine the effects of statin therapy on the progression of atherosclerosis. In one IVUS Study conducted in 36 male CHD patients, pravastatin was observed to reduce plaque index by $7 \%$ compared with an increase of $27 \%$ with placebo $(P<0.0005)$ [91] (Table 1$)$. In a recent, small retrospective study $(N=10)$, IVUS was performed immediately after percutaneous transluminal angioplasty and at 1-year follow up, and revealed that plaque volume in non-dilated segments of artery increased over the study period in both statin-treated and non-statin-treated patients ( +4 and $+2 \%$, respectively) [92]. Increases in plaque volume were accompanied by increases in vessel and lumen size for statin-treated patients $(+2$ and $+1 \%$, respectively) and decreases for patients not receiving statins ( -2 and $-4 \%$, respectively). Although these results did not achieve statistical significance, they support the hypothesis that statin therapy may induce positive remodelling of vascular segments containing atherosclerotic plaques.
The REVERSal of Atherosclerosis with Lipitor (REVERSAL) Trial compared the effects of atorvastatin and pravastatin therapy over 18 months on progression of atherosclerosis measured by IVUS in patients with CHD [59]. Initial data presented at the American Heart Association meeting in 2003 demonstrated significant progression of atherosclerosis with pravastatin $40 \mathrm{mg}$ (mean change in atheroma volume $=2.7 \%, P=0.02$ ), while no change in atherosclerosis progression was observed with atorvastatin $80 \mathrm{mg}$ (mean change in atheroma volume $=-0.4 \%$, $P=0.98)$. Atorvastatin produced a greater reduction in LDL-C compared with pravastatin (46.3\% vs. $25.2 \%$; $P<0.0001)$. In addition, C-reactive protein, a marker of inflammation, was also reduced more by atorvastatin than pravastatin $(-36.4 \%$ vs. $-5.2 \% ; P<0.0001)$ and this was thought to contribute to the difference between treatments on the progression of atherosclerosis.

Other IVUS studies are ongoing, including the Statin on Atherosclerosis and vascular Remodeling assessed with Intravascular Sonography (SARIS) Trial [93]. This is a prospective study designed to assess the morphological and functional cardiovascular effects of atorvastatin in CHD patients with normal to mildly elevated cholesterol levels. The effect of atorvastatin on plaque volume and vascular remodelling will be assessed after 1 year of statin therapy using IVUS. A further IVUS Study, A Study To evaluate the Effect of Rosuvastatin On Intravascular ultrasound-Derived coronary atheroma burden (ASTEROID), will examine the effect of rosuvastatin over 2 years on progression of atherosclerosis in approximately 450 patients with CHD [94].

\subsection{EBCT (coronary calcification) studies}

Callister et al. [73] assessed changes in coronary plaque volume with lipid-lowering therapy using EBCT-derived CVS in asymptomatic, hyperlipidemic patients (Table 1). In this study, CVS of statin-treated patients was compared with that of patients not prescribed statin therapy. Patients treated with a statin were divided into two groups according to whether or not they had achieved a LDL-C level $<3.1 \mathrm{mmol} / 1$ (120 mg/dl). CVS was reduced by $7 \%$ $(P=0.01)$ in patients achieving this LDL-C level, which indicates regression of atherosclerosis in this group. In statin-treated patients who failed to reach this target, an increase in CVS of $25 \%$ was observed. Although this indicates progression of atherosclerosis, the magnitude of the increase was lower than that observed in untreated patients $(25 \%$ vs. $52 \% ; P<0.001)$.

A slowing in the rate of progression of coronary calcification has also been demonstrated with cerivastatin [95] (Table 1) in a study initiated prior to the withdrawal of this drug because of an increased incidence of rhabdomyolysis [104]. The annualized progression rate of coronary calcification over a 1-year treatment period was found to be lower than that during the 14 months prior to initiation of cerivastatin therapy $(8.8 \%$ vs. $25.0 \% ; P=0.0001)$. Another 
EBCT Study, the Beyond Endorsed Lipid Lowering with EBCT Scanning (BELLES) Trial is currently ongoing and will examine the benefits of statin therapy in asymptomatic postmenopausal women [96]. This study will compare the effects of atorvastatin and pravastatin on atherosclerosis progression over 1 year by assessment of the percent change from baseline in each patient's total coronary CVS.

The use of computer tomography techniques to detect coronary calcifications and study progression of atherosclerosis has great potential in cardiovascular research. New developments in computed tomography techniques, such as the multi-slice computed tomography (MSCT) [105-107] provide images of similar quality to EBCT. Their greater availability will facilitate wider use of these techniques both in cardiovascular research and clinical practice.

Despite differences in methodology, the majority of studies have demonstrated that statins, administered at doses used to lower LDL-C levels, are effective in controlling the progression of atherosclerosis in symptomatic and asymptomatic subjects. The effect of statin therapy on atherosclerosis progression appears to be independent of baseline LDL-C and beneficial in patients with subclinical disease.

\section{Future directions in the measurement of atheroscle- rotic burden}

Studies have demonstrated that statins have effects on atherosclerosis progression in addition to LDL-C lowering; these benefits may result from their effects on endothelial dysfunction, platelet deposition, propensity for plaque rupture and thrombosis [21]. Imaging techniques enable direct assessment of statin therapy at the vascular level, at the site of action of these non-lipid effects.

Measurement of the change in atherosclerosis burden, assessed by imaging techniques, allows the clinical benefits of a therapy to be established in a relatively short time and with fewer subjects compared with clinical outcome trials. Significant clinical benefits of statins on markers of atherosclerosis burden have been demonstrated in studies of patients followed up for as little as $12-15$ months using EBCT [73]. Furthermore, the effect of statins on atherosclerotic progression begin to emerge as early as 6 months after the start of therapy in studies assessing CIMT by B-mode ultrasonography $[27,88]$, although this initial change in CIMT may reflect adaptive modifications in response to other factors [48] rather than changes in atherosclerosis progression.

The choice of the most suitable technique for investigating the effects of statins on atherosclerosis progression is determined by a number of factors, including sensitivity and reliability of the imaging method, and whether the procedure is invasive or non-invasive (Table 4). Angiography is well established for the diagnosis of atherosclerosis. Although considered the 'gold standard', a major limitation for the use of angiography in tracking the progression of disease is that it is an invasive procedure requiring specialist personnel to obtain and assess the images. Furthermore, quantitative analysis is time consuming and the visual interpretation of angiograms exhibits significant observer variability and correlates poorly with the extent of atherosclerosis in post-mortem examination [59]. In addition to interscan variability and reproducibility, it has also been suggested that differences may exist between image analysis systems used for quantification [20].

QCA is used to indicate atherosclerotic progression/ regression based upon the visualization of vessel stenoses. However, the smaller, unstable, lipid-rich lesions that are most prone to rupture $[114,115]$ are often angiographically 'silent' as a result of remodelling of the arterial wall [116]. Indeed, $10-15 \%$ of patients undergoing catheterization for suspected coronary disease have normal coronary arteries on angiography [59], although diseased arteries are often detected in these patients using IVUS [61-63]. Furthermore, unstable lesions are more commonly characterized by positive remodelling (expansion) of the arterial wall, whilst negative remodelling (arterial shrinkage) is more often associated with stable plaques [117]. Hence, measurement of stenosis by QCA restricts the assessment of disease progression to plaques at low risk of rupturing. In addition, methodological considerations may limit the use of QCA for tracking plaque progression. The angiographic assessment of a lesion requires comparison of the luminal diameter within the lesion with a 'normal' reference section of artery. However, atherosclerotic disease is usually diffuse and angiographically normal reference sections may contain

Table 4

Comparison of currently available imaging techniques for assessing plaque progression

\begin{tabular}{|c|c|c|c|c|c|c|}
\hline Technique & $\begin{array}{l}\text { Invasive/ } \\
\text { non-invasive }\end{array}$ & $\begin{array}{l}\text { Directly images } \\
\text { arterial wall? }\end{array}$ & $\begin{array}{l}\text { Provides } \\
\text { information on } \\
\text { plaque composition? }\end{array}$ & $\begin{array}{l}\text { Well } \\
\text { validated }\end{array}$ & Sensitivity & Interscan reliability \\
\hline QCA & Invasive & $\mathrm{N}$ & $\mathrm{N}$ & $\mathrm{Y}$ & $\begin{array}{l}\text { Low-only detects } \\
\text { plaques that result } \\
\text { in stenosis }\end{array}$ & $69-93 \%[108,109$ \\
\hline $\begin{array}{l}\text { B-mode } \\
\text { ultrasound }\end{array}$ & Non-invasive & $\mathrm{Y}$ & $\mathrm{Y}$ & $\mathrm{Y}$ & High & $>80 \%[110,111]$ \\
\hline IVUS & Invasive & $\mathrm{Y}$ & $\mathrm{Y}$ & $\mathrm{N}$ & High & $>80 \%[112]$ \\
\hline EBCT & Non-invasive & $\mathrm{N}$ & $\mathrm{Y}$ & $\mathrm{Y}$ & $\begin{array}{l}\text { Moderate-detects } \\
\text { plaques }>5 \mathrm{~mm}^{2}[113]\end{array}$ & $85 \%[74]$ \\
\hline
\end{tabular}


atherosclerotic plaques within the arterial wall [59]. As a consequence of these limitations, QCA may not be the optimal method for assessing the effect of lipid-modifying drugs on atherosclerotic progression/regression, particularly in populations at low risk of $\mathrm{CHD}$ or with subclinical atherosclerosis.

As a result of the limitations of QCA, more sensitive imaging techniques that allow direct imaging of the arterial wall, such as ultrasonography, have been sought. B-mode ultrasonography can be used in asymptomatic patients because of its non-invasive nature. A further advantage of this technique over QCA is that it measures composition of atherosclerotic plaques in addition to size (Table 4). The findings of statin trials have clearly shown that B-mode ultrasonography is a suitable technique for assessing the effects of drug therapies on atherosclerosis progression. The REGRESS Study supports B-mode ultrasonography as a more reliable measure of atherosclerosis burden than QCA; pravastatin therapy was found to significantly reduce progression as indicated by B-mode ultrasound measurement of intima media thickness in the carotid and femoral arteries although no significant effect was observed on angiographically determined luminal diameter [80]. In addition, angiographically 'silent', early atherosclerotic lesions, which derive considerable benefit from statin therapy, can be assessed by measurement of intima media thickness [80]. One limitation of CIMT is that it measures atherosclerosis in the carotid arteries rather than the coronary arteries. Determination of plaque characteristics is only of value in assessing atherosclerotic burden if the plaque measured reflects the type of lesion present elsewhere in the arterial system. For example, it is unlikely that an unstable plaque in the carotid artery will cause a coronary event, however, plaques in the carotid artery may be used as a marker of the type and extent of lesions at other sites in the vasculature that are likely to present a risk to the patient. There is ample evidence that CIMT relates to coronary atherosclerosis, although the relation is not on a one-to-one basis. B-mode ultrasonography is currently the most well-validated method for assessing early changes in disease progression/regression with lipid-modifying therapy because of its sensitivity and non-invasive nature. However, quantitative quality control of sonographers and readers was found to be critical to the success of this technique in intervention studies [118]. The American Heart Association Writing Group III on Non-invasive Tests of Atherosclerotic Burden concluded that with the use of standardized protocols for scanning and monitoring of CIMT, this technique would be useful in the follow up of patients treated for plaque progression or regression [118]. This is reflected in the use of B-mode ultrasonography in the ARBITER and METEOR Studies, which aim to assess the effects of statins on progression of atherosclerosis burden.

IVUS, which exhibits greater sensitivity in detecting plaques compared with QCA, has the additional advantage of assessing plaque composition (Table 4). However, IVUS is invasive and this has limited its use for assessing atheroscle- rotic progression in large population groups that are free from symptomatic CHD. Hence, there are few available data on its use for this application and non-invasive ultrasonographic techniques have been more widely used in intervention studies. Data from the REVERSAL Study and from a recent intervention study with a high-density lipoprotein mimetic (ETC-216) [119] support the use of IVUS in intervention studies. Indeed, treatment-related changes in the rate of atherosclerosis progression measured by IVUS were observed after as little as 5 weeks in the study with ETC-216 [119]. However, further studies are required to validate IVUS fully, and the SARIS and ASTEROID Trials, currently in progress, will provide additional data on the use of this technique for assessing disease progression.

EBCT and MSCT are promising, non-invasive imaging modalities for assessing the effect of therapy on coronary atherosclerosis, as measured by calcifications (Table 4). However, results from intervention studies using EBCT are limited at present and thus its applicability in these settings needs to be assessed in more detail. The increased availability of MSCT scanners, compared with EBCT scanners, may further boost the use of this imaging modality in cardiovascular research.

New non-invasive imaging methods are currently being investigated as suitable techniques for tracking plaque progression. Magnetic resonance imaging (MRI) has excellent soft tissue contrast, permitting visualization and analysis of the components of the atherosclerotic plaque and has the potential to distinguish between stable and unstable lesions [120,121]. Improvements in temporal, spatial and contrast resolution are necessary before the technique can be used clinically for assessing plaque burden [120]. However, MRI is a promising non-invasive method of evaluating both the extent of atherosclerotic lesions and their composition as exemplified by a number of recent studies [122-124].

Recent developments in, and continued validation of, imaging techniques for the measurement of atherosclerosis burden will facilitate the assessment of lipid-modifying therapies on the progression/regression of atherosclerotic disease. This will allow the clinical benefits of these drugs to be more rapidly identified and enable assessment of clinical effect on early and 'silent' atherosclerotic lesions, which may be unlikely to lead to cardiovascular events during the course of a clinical outcomes trial. Statin trials support the use of imaging studies in the assessment of lipid-modifying therapies on disease progression and demonstrate the benefits of early treatment of subclinical atherosclerosis in patients with lipid levels below recommended targets.

\section{Conclusions}

The efficacy of statins in reducing the risk of coronary events has been well established in clinical trials, and imaging techniques have enabled the benefits of statin 
therapy to be demonstrated at the vascular level. Noninvasive techniques for assessing atherosclerotic progression/regression have been developed and have obvious advantages in terms of acceptability to patients and reduced risk of adverse events compared with invasive procedures such as angiography and IVUS. EBCT-assessed coronary calcium is a promising surrogate marker for atherosclerosis progression, and ongoing studies will provide further data on its utility for this application. MRI also has potential for non-invasively measuring the extent of atherosclerosis and for identifying vulnerable plaques based on the analysis of their components.

CIMT, measured by B-mode ultrasonography, is currently the most well-validated, non-invasive technique for tracking plaque progression. CIMT determines plaque size directly rather than estimating plaque burden on the basis of luminal stenosis. Hence, it may be a more sensitive technique for detecting subclinical atherosclerosis and lipid-rich plaques that are vulnerable to rupture.

The use of imaging techniques to quantify the change in atherosclerotic burden with lipid-modifying therapies enables assessment of atherosclerotic progression at the vascular level and allows the clinical benefits of treatment to be identified more rapidly than in clinical outcome trials. Furthermore, these studies support early intervention with statin therapy in patients with subclinical atherosclerotic disease, even in the absence of raised LDL-C levels.

\section{References}

[1] Vogel RA. Cholesterol lowering and endothelial function. Am J Med 1999;107:479-87.

[2] Zaman AG, Helft G, Worthley SG, Badimon JJ. The role of plaque rupture and thrombosis in coronary artery disease. Atherosclerosis 2000;149:251-66

[3] Tuzcu EM, Kapadia SR, Tutar E, et al. High prevalence of coronary atherosclerosis in asymptomatic teenagers and young adults: evidence from intravascular ultrasound. Circulation 2001;103:2705-10.

[4] Libby P. Changing concepts of atherogenesis. J Intern Med 2000; 247:349-58.

[5] Glagov S, Weisneberg E, Zarins CK, Stankunavicius R, Kolettis GJ. Compensatory enlargement of human atherosclerotic coronary arteries. N Engl J Med 1987;316:1371-5.

[6] Falk E. Coronary thrombosis: pathogenesis and clinical manifestations. Am J Cardiol 1991;68:28B-35B.

[7] Thomas AC, Knapman PA, Krikler DM, Davies MJ. Community study of the causes of "natural" sudden death. BMJ 1988;297: $1453-6$

[8] Leach IH, Blundell JW, Rowley JM, Turner DR. Acute ischaemic lesions in death due to ischaemic heart disease. An autopsy study of 333 cases of out-of-hospital death. Eur Heart J 1995;16:1181-5.

[9] Castelli WP, Anderson K, Wilson PWF, Levy D. Lipids and risk of coronary heart disease. The Framingham Study. Ann Epidemiol 1992;2:23-8.

[10] Law MR, Wald NJ, Wu T, Hackshaw A, Bailey A. Systematic underestimation of association between serum cholesterol concentration and ischaemic heart disease in observational studies: data from the BUPA Study. BMJ 1994;308:363-6.
[11] Wood D, De Backer G, Faergeman O, Graham I, Mancia G, Pyörälä $\mathrm{K}$. Prevention of coronary heart disease in clinical practice: recommendations of the Second Joint Task Force of European and other societies on coronary prevention. Eur Heart J 1998;19:1434-503.

[12] Expert Panel on Detection, Evaluation, and Treatment of High Blood Cholesterol in Adults. Executive summary of the third report of the National Cholesterol Education Program (NCEP) expert panel on detection, evaluation, and treatment of high blood cholesterol in adults (Adult Treatment Panel III). JAMA 2001;285:2486-97.

[13] Shepherd J, Cobbe SM, Ford I, et al. Prevention of coronary heart disease with pravastatin in men with hypercholesterolemia. N Engl J Med 1995;333:1301-7.

[14] Downs JR, Clearfield M, Weis S, et al. Primary prevention of acute coronary events with lovastatin in men and women with average cholesterol levels. Results of AFCAPS/TexCAPS. Air Force/Texas Coronary Atherosclerosis Prevention Study. JAMA 1998;279: $1615-22$

[15] Sacks FM, Pfeffer MA, Moye LA, et al. The effect of pravastatin on coronary events after myocardial infarction in patients with average cholesterol levels. N Engl J Med 1996;335:1001-9.

[16] The Long-Term Intervention with Pravastatin in Ischaemic Disease (LIPID) Study Group. Prevention of cardiovascular events and death with pravastatin in patients with coronary heart disease and a broad range of initial cholesterol levels. N Engl J Med 1998;339: $1349-57$.

[17] Scandinavian Simvastatin Survival Study Group. Randomised trial of cholesterol lowering in 4444 patients with coronary heart disease: the Scandinavian Simvastatin Survival Study (4S). Lancet 1994; 344:1383-9.

[18] Heart Protection Study Collaborative Group. MRC/BHF Heart Protection Study of cholesterol lowering with simvastatin in 20536 high-risk individuals: a randomised placebo-controlled trial. Lancet 2002;360:7-22.

[19] MAAS investigators. Effect of simvastatin on coronary atheroma: the Multicentre Anti-Atheroma Study (MAAS). Lancet 1994; 344:633-8

[20] Jukema JW, Bruschke AVG, van Boven AJ, et al. Effect of lipid lowering by pravastatin on progression of coronary artery disease in symptomatic men with normal to moderately elevated serum cholesterol levels. The Regression Growth Evaluation Statin Study (REGRESS). Circulation 1995;91:2528-40.

[21] Pitt B, Mancini GBJ, Ellis SG, Rosman HS, Park J-S, McGovern ME. Pravastatin limitation of atherosclerosis in the coronary arteries (PLAC I): reduction in atherosclerosis progression and clinical events. PLAC I Investigations. J Am Coll Cardiol 1995;26:1133-9.

[22] Gensini GG. A more meaningful scoring system for determining the severity of coronary heart disease. Am J Cardiol 1983;51:606.

[23] Azen SP, Mack WJ, Cashin-Hemphill L, et al. Progression of coronary artery disease predicts clinical coronary events. Long-term follow-up from the Cholesterol Lowering Atherosclerosis Study. Circulation 1996;93:34-41.

[24] Mack WJ, Xiang M, Selzer RH, Hodis HN. Serial quantitative coronary angiography and coronary events. Am Heart J 2000; 139:993-9.

[25] Mack WJ, La Bree L, Liu C, Selzer RH, Hodis HN. Correlations between measures of atherosclerosis change using carotid ultrasonography and coronary angiography. Atherosclerosis 2000;150: $371-9$.

[26] Okayama H, Sumimoto T, Morioka N, Hiasa G, Yamamoto K, Kawada H. Association of coronary artery disease with intimal-medial thickness and atheromatous plaque of carotid artery. Eur Heart $\mathrm{J}$ 2001;22:273 [Abstr Suppl].

[27] Mercuri M, Bond MG, Sirtori CR, et al. Pravastatin reduces carotid intima-media thickness progression in an asymptomatic hypercholesterolemic Mediterranean population: the Carotid Atherosclerosis Italian Ultrasound Study. Am J Med 1996;101:627-34.

[28] Pignoli P, Tremoli E, Poli A, Oreste P, Paoletti R. Intimal plus 
medial thickness of the arterial wall: a direct measurement with ultrasound imaging. Circulation 1986;74:1399-406.

[29] Geroulakos G, O’Gorman DJ, Kalodiki E, Sheridan DJ, Nicolaides AN. The carotid intima-media thickness as a marker for the presence of severe symptomatic coronary artery disease. Eur Heart J 1994; 15:781-5.

[30] Bots ML, Hoes AW, Hofman A, Witteman JC, Grobbee DE. Crosssectionally assessed carotid intima-media thickness relates to longterm risk of stroke, coronary heart disease and death as estimated by available risk functions. J Intern Med 1999;245:269-76.

[31] Simons PC, Algra A, Bots ML, Grobbee DE, van der Graaf Y. Common carotid intima-media thickness and arterial stiffness: indicators of cardiovascular risk in high-risk patients. The SMART Study (Second Manifestations of ARTerial disease). Circulation 1999;100:951-7.

[32] Bots ML, Witteman JC, Grobbee DE. Carotid intima-media wall thickness in elderly women with and without atherosclerosis of the abdominal aorta. Atherosclerosis 1993;102:99-105.

[33] Bots ML, Hofman A, Grobbee DE. Common carotid intima-media thickness and lower extremity arterial atherosclerosis. The Rotterdam Study. Arterioscler Thromb 1994;14:1885-91.

[34] Allan PL, Mowbray PI, Lee AJ, Fowkes FG. Relationship between carotid intima-media thickness and symptomatic and asymptomatic peripheral arterial disease. The Edinburgh Artery Study. Stroke 1997;28:348-53.

[35] Mattace RF, Rosato M, Talerico A, Cotronei P, Mattace R. Intimalmedial thickness of the common carotid arteries and lower limbs atherosclerosis in the elderly. Minerva Cardioangiol 1999;47:321-7.

[36] Davis PH, Dawson JD, Mahoney LT, Lauer RM. Increased carotid intimal-medial thickness and coronary calcification are related in young and middle-aged adults. The Muscatine Study. Circulation 1999; 100:838-42.

[37] Arad Y, Spadaro LA, Roth M, et al. Correlations between vascular calcification and atherosclerosis: a comparative electron beam CT study of the coronary and carotid arteries. J Comput Assist Tomogr 1998;22:207-11.

[38] Vliegenthart R, Oudkerk M, Song B, et al. Coronary calcification detected by electron-beam computed tomography and non-coronary measures of atherosclerosis: the Rotterdam Study. Circulation 2001;103:1344.

[39] Crouse III JR, Craven TE, Hagaman AP, Bond MG. Association of coronary disease with segment-specific intimal-medial thickening of the extracranial carotid artery. Circulation 1995;92:1141-7.

[40] Adams MR, Nakagomi A, Keech A, et al. Carotid intima-media thickness is only weakly correlated with the extent and severity of coronary artery disease. Circulation 1995;92:2127-34.

[41] de Groot E, Jukema JW, van Boven AJ, et al. Effect of pravastatin on progression and regression of coronary atherosclerosis and vessel wall changes in carotid and femoral arteries: a report from the Regression Growth Evaluation Statin Study. Am J Cardiol 1995; 76:40C-6C.

[42] Visona A, Pesavento R, Lusiani L, et al. Intimal medial thickening of common carotid artery as indicator of coronary artery disease. Angiology 1996;47:61-6.

[43] Hulthe J, Wikstrand J, Emanuelsson H, et al. Atherosclerotic changes in the carotid artery bulb as measured by B-mode ultrasound are associated with the extent of coronary atherosclerosis. Stroke 1997;28:1189-94.

[44] Khoury Z, Schwartz R, Gottlieb S, et al. Relation of coronary artery disease to atherosclerotic disease in the aorta, carotid, and femoral arteries evaluated by ultrasound. Am J Cardiol 1997;80:1429-33.

[45] Enderle MD, Schroeder S, Ossen R, et al. Comparison of peripheral endothelial dysfunction and intimal media thickness in patients with suspected coronary artery disease. Heart 1998;80:349-54.

[46] Lekakis JP, Papamichael CM, Cimponeriu AT, et al. Atherosclerotic changes of extracoronary arteries are associated with the extent of coronary atherosclerosis. Am J Cardiol 2000;85:949-52.
[47] Balbarini A, Buttitta F, Limbruno U, et al. Usefulness of carotid intima-media thickness measurement and peripheral B-mode ultrasound scan in the clinical screening of patients with coronary artery disease. Angiology 2000;51:269-79.

[48] Bots ML, Hoes AW, Koudstaal PJ, Hofman A, Grobbee DE. Common carotid intima-media thickness and risk of stroke and myocardial infarction: the Rotterdam Study. Circulation 1997;96: $1432-7$.

[49] Chambless LE, Heiss G, Folsom AR, Rosamond W, Szklo M, Sharrett $\mathrm{AR}$, et al. Association of coronary heart disease incidence with carotid arterial wall thickness and major risk factors: the Atherosclerosis Risk in Communities (ARIC) Study, 1987-1993. Am J Epidemiol 1997;146:483-94.

[50] Hodis HN, Mack WJ, LaBree L, Selzer RH, Liu CH, Azen SP. The role of carotid arterial intima-media thickness in predicting clinical coronary events. Ann Intern Med 1998;128:262-9.

[51] O'Leary DH, Polak JF, Kronmal RA, Manolio TA, Burke GL, Wolfson SK. Carotid-artery intima and media thickness as a risk factor for myocardial infarction and stroke in older adults. Cardiovascular Health Study Collaborative Research Group. N Engl J Med 1999; 340:14-22.

[52] Chambless LE, Folsom AR, Clegg LX, et al. Carotid wall thickness is predictive of incident clinical stroke: the Atherosclerosis Risk in Communities (ARIC) Study. Am J Epidemiol 2000;151:478-87.

[53] Yamasaki Y, Kodama M, Nishizawa H, et al. Carotid intima-media thickness in Japanese type 2 diabetic subjects: predictors of progression and relationship with incident coronary heart disease. Diabetes Care 2000;23:1310-5.

[54] del Sol AI, Moons KG, Hollander M, et al. Is carotid intima-media thickness useful in cardiovascular disease risk assessment? The Rotterdam Study. Stroke 2001;32:1532-8.

[55] Held C, Hjemdahl P, Eriksson SV, Bjorkander I, Forslund L, Rehnqvist N. Prognostic implications of intima-media thickness and plaques in the carotid and femoral arteries in patients with stable angina pectoris. Eur Heart J 2001;22:62-72.

[56] Mannami T, Konishi M, Baba S, Nishi N, Terao A. Prevalence of asymptomatic carotid atherosclerotic lesions detected by high-resolution ultrasonography and its relation to cardiovascular risk factors in the general population of a Japanese city: the Suita Study. Stroke 1997;28:518-25.

[57] Handa N, Matsumoto M, Maeda $\mathrm{H}$, et al. Ultrasonic evaluation of early carotid atherosclerosis. Stroke 1990;21:1567-72.

[58] Hedblad B, Wikstrand J, Janzon L, Wedel H, Berglund G. Low-dose metroprolol $\mathrm{CR} / \mathrm{XL}$ and fluvastatin slow progression of carotid intima-media thickness: main results from the Beta-Blocker Cholesterol-Lowering Asymptomatic Plaque Study (BCAPS). Circulation 2001;103:1721-6.

[59] Nissen SE, Yock P. Intravascular ultrasound: novel pathophysiological insights and current clinical applications. Circulation 2001; 103:604-16.

[60] Mintz GS, Nissen SE, Anderson WD, et al. American college of cardiology: clinical expert consensus document on standards for acquisition, measurement and reporting of Intravascular Ultrasound Studies (IVUS). J Am Coll Cardiol 2001;37:1478-92.

[61] Topol EJ, Nissen SE. Our preoccupation with coronary luminology. The dissociation between clinical and angiographic findings in ischemic heart disease. Circulation 1995;92:2333-42.

[62] Erbel R, Ge J, Bockisch A, et al. Value of intracoronary ultrasound and Doppler in the differentiation of angiography normal coronary arteries: a prospective study in patients with angina pectoris. Eur Heart J 1996;17:880-9.

[63] Mintz GS, Painter JA, Pichard AD, et al. Atherosclerosis in angiographically "normal" coronary artery reference segments: an intravascular ultrasound study with clinical correlations. J Am Coll Cardiol 1995;25:1479-85.

[64] O'Rourke RA, Brundage BH, Froelicher VF, et al. American College of Cardiology/American Heart Association expert consensus 
document on electron-beam computed tomography for the diagnosis and prognosis of coronary artery disease. Circulation 2000;102: $126-40$

[65] Wexler L, Brundage B, Crouse J, et al. Coronary artery calcification: pathophysiology, epidemiology, imaging methods, and clinical implications. A statement for health professionals from the American Heart Association. Circulation 1996;94:1175-92.

[66] Boström K, Watson KE, Horn S, Wortham C, Herman IM, Demer LL. Bone morphogenetic protein expression in human atherosclerotic lesions. J Clin Invest 1993;91:1800-9.

[67] Agatston AS, Janowitz WR, Hildner FJ, Zusmer NR, Viamonte Jr M, Detrano R. Quantification of coronary artery calcium using ultrafast computed tomography. J Am Coll Cardiol 1990;15:827-32.

[68] Arad Y, Newstein D, Cadet F, Roth M, Guerci AD. Association of multiple risk factors and insulin resistance with increased prevalence of asymptomatic coronary artery disease by an electron-beam computed tomographic study. Arterioscler Thromb Vasc Biol 2001;21: 2051-8.

[69] Newman AB, Naydeck BL, Sutton-Tyrrell K, Feldman A, Edmundowicz D, Kuller LH. Coronary artery calcification in older adults to age 99: prevalence and risk factors. Circulation 2001;104:2679-84.

[70] Mahoney LT, Burns TL, Stanford W, et al. Usefulness of the Framingham risk score and body mass index to predict early coronary artery calcium in young adults (Muscatine Study). Am J Cardiol 2001;88:509-15.

[71] Raggi P, Callister TQ, Davidson M, et al. Aggressive versus moderate lipid-lowering therapy in postmenopausal women with hypercholesterolemia: rationale and design of the Beyond Endorsed Lipid Lowering with EBT Scanning (BELLES) Trial. Am Heart J 2001;141:722-6.

[72] Vliegenthart R, Hollander M, Breteler MM, et al. Stroke is associated with coronary calcification as detected by electron-beam CT: the Rotterdam Coronary Calcification Study. Stroke 2002;33:462-5.

[73] Callister TQ, Raggi P, Cooil B, Lippolis NJ, Russo DJ. Effect of HMG-CoA reductase inhibitors on coronary artery disease as assessed by electron-beam computed tomography. N Engl J Med 1998;339:1972-8.

[74] Callister TQ, Cooil B, Raya SP, Lippolis NJ, Russon DJ, Raggi P. Coronary artery disease: improved reproducibility of calcium scoring with an electron-beam CT volumetric method. Radiology 1998;208:807-14.

[75] Blankenhorn DH, Azen SP, Kramsch DM, et al. Coronary angiographic changes with lovastatin therapy. The Monitored Atherosclerosis Regression Study (MARS). The MARS Research Group. Ann Intern Med 1993;119:969-76.

[76] Waters D, Higginson L, Gladstone P, et al. Effects of monotherapy with an HMG-Co A reductase inhibitor on the progression of coronary atherosclerosis as assessed by serial quantitative arteriography. The Canadian Coronary Atherosclerosis Intervention Trial. Circulation 1994;89:959-68.

[77] Herd JA, Ballantyne CM, Farmer JA, et al. Effects of fluvastatin on coronary atherosclerosis in patients with mild to moderate cholesterol elevations (Lipoprotein and Coronary Atherosclerosis Study [LCAS]). Am J Cardiol 1997;80:278-86.

[78] Bestehorn HP, Rensing UFE, Roskamm H, et al. The effect of simvastatin on progression of coronary artery disease. The Multicenter Coronary Intervention Study (CIS). Eur Heart J 1997;18:226-34.

[79] Teo KK, Burton JR, Buller CE, et al. Long-term effects of cholesterol lowering and angiotensin-converting enzyme inhibition on coronary atherosclerosis: the Simvastatin/Enalapril Coronary Atherosclerosis Trial (SCAT). Circulation 2000;102:1748-54.

[80] de Groot E, Jukema JW, Montauban van Swijndregt AD, et al. Bmode ultrasound assessment of pravastatin treatment effect on carotid and femoral artery walls and its correlations with coronary arteriographic findings: a report of the Regression Growth Evaluation Statin Study (REGRESS). J Am Coll Cardiol 1998;31:1561-7.

[81] Crouse III JR, Byington RP, Bond MG, et al. Pravastatin, lipids and atherosclerosis in the carotid arteries (PLAC II). Am J Cardiol 1995;75:455-9.

[82] Byington RB, Furberg CD, Crouse III JR, Espeland MA, Bond MG. Pravastatin, lipids and atherosclerosis in the carotid arteries (PLACII). Am J Cardiol 1995;76:54C-9C.

[83] MacMahon S, Sharpe N, Gamble G, et al. Effects of lowering average or below-average cholesterol levels on the progression of carotid atherosclerosis. Results of the LIPID atherosclerosis substudy. LIPID Trial Research Group. Circulation 1998;97:1784-90.

[84] Hodis HN, Mack WJ, LaBree L, et al. Reduction in carotid arterial wall thickness using lovastatin and dietary therapy: a randomized controlled clinical trial. Ann Intern Med 1996;124:548-56.

[85] Smilde TJ, van Wissen S, Wollersheim H, Trip MD, Kastelein JJP, Stalenhoef AFH. Effect of aggressive versus conventional lipid lowering on atherosclerosis progression in familial hypercholesterolaemia (ASAP): a prospective, randomised, double-blind trial. Lancet 2001;357:577-81.

[86] Markwood TT, Kent SM, Coyle LC, Flaherty PJ, O’Malley PG, Taylor AJ. Design and rationale of the ARBITER trial (Arterial Biology for the Investigation of the Treatment Effects of Reducing Cholesterol) - a randomized trial comparing the effects of atorvastatin and pravastatin on carotid artery intima-media thickness. Am Heart J 2001;141:342-7.

[87] Taylor AJ, Kent SM, Flaherty PJ, Coyle LC, Markwood TT, Vernalis MN. ARBITER: Arterial Biology for the Investigation of the Treatment Effects of Reducing Cholesterol: a randomized trial comparing the effects of atorvastatin and pravastatin on carotid intima medial thickness. Circulation 2002;106:2055-60.

[88] Furberg CD, Adams Jr HP, Applegate WB, et al. Effect of lovastatin on early carotid atherosclerosis and cardiovascular events. Asymptomatic Carotid Artery Progression Study (ACAPS) Research Group. Circulation 1994;90:1679-87.

[89] Salonen R, Nyyssönen K, Porkkala E, et al. A population-based primary preventative trial of the effect of LDL lowering on atherosclerosis progression in carotid and femoral arteries. Circulation 1995;92:1758-64.

[90] Crouse III JR, Grobbee DE, O'Leary DH, et al. Measuring effects on intima media thickness: an evaluation of rosuvastatin - the METEOR Study. Artheroscler Suppl 2002;3:94.

[91] Takagi T, Yoshida K, Akasaka T, Hozumi T, Morioka S, Yoshikawa J. Intravascular ultrasound analysis of reduction in progression of coronary narrowing by treatment with pravastatin. Am J Cardiol 1997;79:1673-6.

[92] Hagenaars T, Gussenhoven EJ, Kranendonk SE, et al. Early experience with intravascular ultrasound in evaluating the effect of statins on femoropopliteal arterial disease: hypothesis-generating observations in humans. Cardiovasc Drugs Ther 2000;14:635-41.

[93] Hagenaars T, Gussenhoven EJ, Poldermans D, van Urk H, van der Lugt A. Rationale and design for the SARIS trial; effect of statin on atherosclerosis and vascular remodeling assessed with intravascular sonography. Effect of statin on atherosclerosis and vascular remodeling assessed with intravascular sonography. Cardiovasc Drugs Ther 2001;15:339-43.

[94] Nissen S, on behalf of the ASTEROID Study Group. Design and methodology of a study to evaluate the effect of rosuvastatin on intravascular ultrasound-derived coronary atheroma burden: the ASTEROID Study. Artheroscler Suppl 2003;4:27.

[95] Achenbach S, Ropers D, Pohle K, et al. Influence of lipid-lowering therapy on the progression of coronary artery calcification: a prospective evaluation. Circulation 2002;106:1077-82.

[96] Raggi P. The use of electron-beam computed tomography as a tool for primary prevention. Am J Cardiol 2001;88:28J-32J.

[97] Expert Panel on Detection, Evaluation, and Treatment of High Blood Cholesterol in Adults. National cholesterol education program. second report of the expert panel on detection, evaluation, and treatment of high blood cholesterol in adults. (Adult Treatment Panel II). Circulation 1994;89:1333-45. 
[98] Gotto Jr AM, Farmer JA. Pleiotropic effects of statins: do they matter? Curr Opin Lipidol 2001;12:391-4.

[99] Davidson M, Ma P, Stein EA, et al. Comparison of effects on lowdensity lipoprotein cholesterol and high-density lipoprotein cholesterol with rosuvastatin versus atorvastatin in patients with type IIa or IIb hypercholesterolemia. Am J Cardiol 2002;89:268-75.

[100] Paoletti R, Fahmy M, Mahla G, Mizan J, Southworth H. Rosuvastatin demostrates greater reduction of low-density lipoprotein cholesterol compared with pravastatin and simvastatin in hypercholesterolaemic patients: a randomized double-blind trial. J Cardiovasc Risk 2001;8:383-90.

[101] Olsson AG, Pears J, McKellar J, Mizan J, Raza A. Effect of rosuvastatin on low-density lipoprotein cholesterol in patients with hypercholesterolemia. Am J Cardiol 2001;88:504-8.

[102] Brown WV, Zedler BK, Bays HE, Hassman HA, Chitra RR, Miller E. Long-term efficacy and safety of rosuvastatin: results of a 52week comparator-controlled trial versus pravastatin and simvastatin. Eur Heart J 2001;22:270 [Abstr. Suppl.].

[103] Jones PH, Davidson MH, Stein EA, et al, STELLAR Study Group. Comparison of the efficacy and safety of rosuvastatin versus atorvastatin, simvastatin, and pravastatin across doses (STELLAR* Trial). Am J Cardiol 2003;92:152-60.

[104] Furberg CD, Pitt B. Withdrawal of cerivastatin from the world market. Curr Control Trials, Cardiovasc Med 2001;2:205-7.

[105] Prokop M. Multislice CT angiography. Eur J Radiol 2000;36:86-96.

[106] Nieman K, Oudkerk M, Rensing BJ, et al. Coronary angiography with multi-slice computed tomography. Lancet 2001;357:599-603.

[107] Achenbach S, Giesler T, Ropers D, et al. Detection of coronary artery stenoses by contrast-enhanced, retrospectively electrocardiographically-gated, multislice spiral computed tomography. Circulation 2001;103:2535-8.

[108] DeRouen TA, Murray JA, Owen W. Variability in the analysis of coronary arteriograms. Circulation 1977;55:324-8.

[109] Beauman GJ, Vogel RA. Accuracy of individual and panel visual interpretations of coronary arteriograms: implications for clinical decisions. J Am Coll Cardiol 1990;16:108-13.

[110] Kanters SDJM, Algra A, van Leeuwen MS, Banga JD. Reproducibility of in vivo carotid intima-media thickness measurements: a review. Stroke 1997;28:665-71.

[111] Tang R, Hennig M, Thomasson B, et al. Baseline reproducibility of B-mode ultrasonic measurement of carotid artery intima-media thickness: the European Lacidipine Study on Atherosclerosis (ELSA). J Hypertens 2000;18:197-201.
[112] Bocksch W, Wellnhofer E, Schartl M, et al. Reproducibility of serial intravascular ultrasound measurements in patients with angiographically silent coronary artery disease after heart transplantation. Coron Artery Dis 2000;11:555-62.

[113] Rumberger JA, Simons DB, Fitzpatrick LA, Sheedy PF, Schwartz RS. Coronary artery calcium areas by electron beam computed tomography and coronary atherosclerotic plaque area: a histopathologic correlative study. Circulation 1995;92:2157-62.

[114] Fuster V, Badimon L, Badimon JJ, Chesebro JH. The pathogenesis of coronary artery disease and the acute coronary syndromes (1). N Engl J Med 1992;326:242-50.

[115] Fuster V, Badimon L, Badimon JJ, Chesebro JH. The pathogenesis of coronary artery disease and the acute coronary syndromes (2). N Engl J Med 1992;326:310-8.

[116] Nissen S. Coronary angiography and intravascular ultrasound. Am J Cardiol 2001;87:15A-20A.

[117] Smits PC, Pasterkamp G, Quarles van Ufford MA, et al. Coronary artery disease: arterial remodelling and clinical presentation. Heart 1999;81:461-4.

[118] Greenland P, Abrams J, Aurigemma GP, et al. Prevention conference $\mathrm{V}$ : beyond secondary prevention: identifying the high-risk patient for primary prevention: noninvasive tests of atherosclerotic burden: Writing Group III. Circulation 2000;101:e16-22.

[119] Nissen SE, Tsunoda T, Tuzcu EM, et al. Effect of recombinant ApoA-I Milano on coronary atherosclerosis in patients with acute coronary syndromes: a randomized controlled trial. JAMA 2003; 290:2292-300.

[120] Moshage W, Achenbach S, Daniel WG. Novel approaches to the non-invasive diagnosis of coronary-artery disease. Nephrol Dial Transplant 2001;16:21-8.

[121] Fayad ZA, Fuster V. The human high-risk plaque and its detection by magnetic resonance imaging. Am J Cardiol 2001;88:42E-5E.

[122] Chan SK, Jaffer A, Botnar RM, et al. Scan reproducibility of magnetic resonance imaging assessment of aortic atherosclerosis burden. J Cardiovasc Magn Reson 2001;3:331-8.

[123] Zhao XQ, Yuan C, Hatsukami TS, et al. Effects of prolonged intensive lipid-lowering therapy on the characteristics of carotid atherosclerotic plaques in vivo by MRI: a case-control study. Arterioscler Thromb Vasc Biol 2001;21:1623-9.

[124] Yuan C, Kerwin WS, Ferguson MS, et al. Contrast-enhanced high resolution MRI for atherosclerotic carotid artery tissue characterization. J Magn Reson Imaging 2002;15:62-7. 